\title{
COMPARATIVE CYTOTOXIC ACTIVITY OF CARBOPLATIN AND $\beta$-CRYPTOXANTHIN IN FREE AND LIPOSOMAL FORMS AGAINST BREAST CANCER CELL LINE
}

\author{
M. W. SHAFAA ${ }^{凶}$, N. S. ELKHOLY \\ Physics Department, Medical Biophysics Division, Faculty of Science, \\ Helwan University, Cairo, Egypt; \\ 凶e-mail: medhatwi@hotmail.com
}

Received: 1 June 2020; Accepted: 17 May 2021

\begin{abstract}
The study of the effectiveness of the synthetic and natural anticarcinogenic compounds in liposomal form is urgent for their possible use in therapy. In this work, the alkylating agent carboplatin and the representative of carotenoids $\beta$-cryptoxanthin were used. The aim of the research was to study the toxicity of these compounds in free and liposomal forms against breast cancer MCF-7 cell line. According to DSC and FTIR data, when carboplatin or $\beta$-cryptoxanthin were added to liposomal bilayers, a single peak was observed indicating their mutual mixing. Integration of $\beta$-cryptoxanthin into bilayer was found to be more proper for the creation of PE acyl chains ordered and cooperative state. It was found that MCF-7 cells sensitivity was much higher to the free $\beta$-cryptoxanthin than to the free carboplatin with $I C_{50} 42$ and $235 \mu \mathrm{g} / \mathrm{ml}$, respectively. The $I C_{50}$ values for $\beta$-cryptoxanthin loaded into liposomes and for free carboplatin were similar. At the same time, no cytotoxic effect of carboplatin-loaded liposomes was observed. The data obtained allow proposing a possible antitumor treatment regimen where carboplatin is replaced by free $\beta$-cryptoxanthin or its liposomal form to increase the effectiveness of breast cancer therapy.
\end{abstract}

Keywords: $\beta$-cryptoxanthin, carboplatin, liposomes, DSC, FTIR, MCF-7 cancer cell line, cytotoxicity.

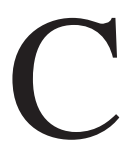
ancer is characterized by the uncontrolled growth and proliferation of abnormal cells that can invade or spread to other parts of the body. If the spread is not managed, then it can result in death. Treatments include surgery, radiation, chemotherapy, hormone therapy, immune and targeted therapy [1]

Breast cancer is the second leading carcinogenic disease as the most common non-cutaneous malignancy among women. Options for treating breast cancer are limited and linked to toxicity. Emerging nanotechnologies have exhibited the potential to treat or target breast cancer. Over the years, different lipid nanoparticles for breast cancer therapy have been created, namely liposomes, solid lipid nanoparticles, nanostructured lipid carriers, and lipid polymer hybrid nanoparticles [2, 3].
All hydrophilic and lipophilic drugs can be encapsulated and protected from degradation by liposomes, the vesicles of phospholipid bilayers. The liposomal similarity to the membrane bilayer core makes liposomes a very useful tool for examining the importance of drug-membrane interactions with anticancer.

By prolonging biological half-life or reducing toxicity, liposomes have been used to enhance the therapeutic index of new or established drugs $[4,5]$. Liposomal clinical applications are a large area of research where cancer therapy is the area of greatest impact [6, 7].

Carboplatin is one of the platinum anti-cancer compounds and its parent compound is cisplatin with a carboxy-cyclobutane moiety instead of the chloride atoms which makes it more stable and perhaps less

(C) 2021 Shafaa MW, Elkholy NS. This is an open-access article distributed under the terms of the Creative Commons Attribution License, which permits unrestricted use, distribution, and reproduction in any medium, provided the original author and source are credited. 
toxic than cisplatin. Carboplatin and cisplatin act as alkylating agents causing cross-linkage between and within DNA strands, resulting in inhibition of DNA, RNA, and protein synthesis and triggering programmed cell death, often in rapidly dividing cells. It causes the development of free radicals or reactive oxygen species. Free radicals cause cellular damage in many ways due to their high chemical reactivity. DNA damage, which can lead to a number of pathological conditions, including cancer, is among the most damaging effects of free radicals. [8]. Cisplatin and carboplatin are effective chemotherapy drugs commonly used to treat solid tumors such as cancer of the testicles, ovaries, cervix, lungs, head and neck, esophagus, and bladder [9]. Cisplatin and carboplatin have been investigated in metastatic breast cancer as monotherapies and in combination with other chemotherapeutic agents. [10].

Carotenoids are among the bioactive substances that have a potential impact on cancer risk and progression and have been the focus of numerous investigations [11, 12]. Carotenoids are naturally occurring organic compounds in plants and photosynthetic organisms such as algae [13, 14]. Present reports suggest they have identified $>600$ carotenoids. However, as a result of selective digestive tract uptake, only 14 carotenoids with their metabolites were found in human plasma and peripheral tissues [15].

Several studies have shown that diets rich in vegetables and fruit can reduce the risk of multiple chronic diseases, including cancer, cardiovascular diseases, and diabetes [16]. In addition to $\beta$-cryptoxanthin, various carotenoids show more potent activity to suppress the carcinogenic process. Evidence shows that $\beta$-cryptoxanthin has a potent antioxidant ability in vitro and can defend human cells from oxidative damage, contributing to inflammation suppression, even serving as a scavenger of free radicals, and preventing biomolecules such as lipids, proteins, and nucleic acids from oxidative damage. [17-19]. Carotenoids have numerous pathways to exhibit anticancer and cancer prevention mechanisms, including antioxidant and direct antiproliferative effects (induction of apoptosis) and inhibition of oncogene expression and angiogenesis [20].

To our knowledge, no previous studies on the interaction of $\beta$-cryptoxanthin or carboplatin with phospholipids were performed from the perspective of the thermotropic phase behavior of phospholipids and to detect the changes of acyl chain conformations and characteristic $\mathrm{PO}_{2}^{-}$bands in the polar heads of phospholipids. To date, the anti-proliferative activity of $\beta$-cryptoxanthin in free and nanoliposomal forms towards MCF-7 (Breast cancer cell line) has not yet been studied.

The objective of this study was to determine whether free or integrated $\beta$-cryptoxanthin in liposomes could inhibit the proliferation of human MCF-7 cell breast cancer by detecting the possible effects of these compounds on the cell death of human MCF-7 cell line carcinoma compared to free carboplatin and its conjugation with liposomes. The formulated $\beta$-cryptoxanthin or carboplatin/liposomal conjugate was characterized by analytical techniques to evaluate the size, size distribution, thermotropic and conformation changes of the formulated $\beta$-cryptoxanthin or carboplatin/liposomal conjugate along with in vitro possible cytotoxicity against MCF-7 (breast cancer cell line).

\section{Material and Methods}

Chemicals. $\beta$-cryptoxanthin was purified from natural sources and verified for purity by TLC and HPLC. The structure of $\beta$-cryptoxanthin was confirmed from spectral data and elemental analysis. The molecular weight of $\beta$-cryptoxanthin is 552.85. Carboplatin with a molecular weight of 371.25, was purchased from Asta (Germany). The molecular structure of $\beta$-cryptoxanthin and Carboplatin are shown in Fig. 1. Ethanol was of analytical grade and was bought from DaeJung
$\boldsymbol{A}$

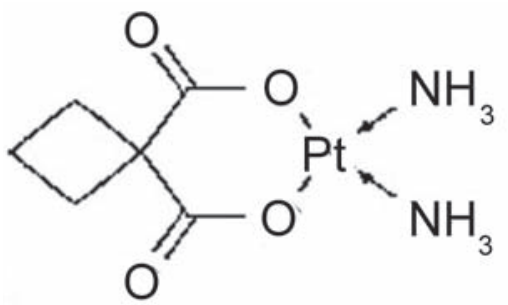

$B$

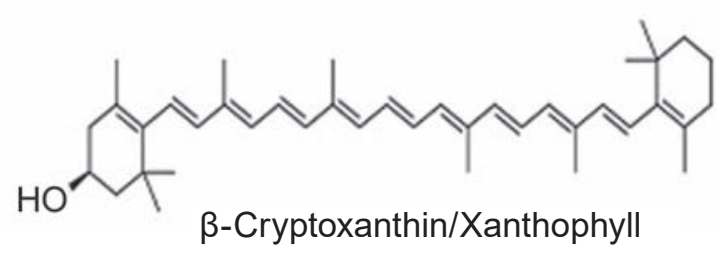

Fig. 1. The chemical structure of carboplatin (A) and $\beta$-cryptoxanthin (B) 


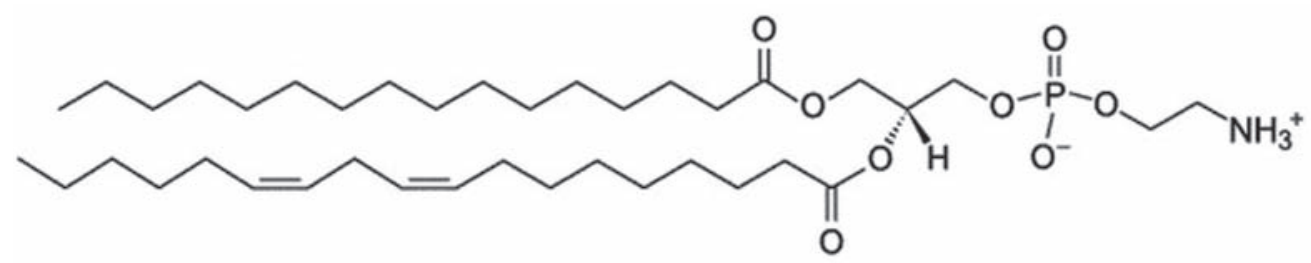

Fig. 2. Schematic chemical structure of L- $\alpha$-phosphatidylethanolamine

Chemicals (Seohaean-ro, Gyeonggi-do, Korea). L- $\alpha$ Phosphatidylethanolamine (PE) from sheep brain with a molecular weight of 691.515 of purity $\geq 98 \%$ bought from Sigma (ST. Louis, Mo, USA) is presented in (Figure 2), Bought from CDH, New Delhi, India, Tris base in powder form, the molecular weight of 121.1. Human tumor cell line MCF 7 was obtained frozen in liquid nitrogen $\left(-180^{\circ} \mathrm{C}\right)$ from the American Type Culture Collection. The tumor cell lines were maintained in the National Cancer Institute, Cairo, Egypt, by serial sub-culturing. Dimethylsulphoxide (DMSO), RPMI-1640 medium, Sodium bicarbonate, Trypan blue: An isotonic solution of $0.05 \%$ trypan blue in normal saline, Fetal bovine serum (FBS), Penicillin/Streptomycin, Trypsin, Acetic acid, Sulphorhodamine-B (SRB), $0.4 \%$ SRB dissolved in $1 \%$ acetic acid, Trichloroacetic acid (TCA), 100\% isopropanol were obtained from (Sigma Chemical Co., St. Louis, Mo, USA). Solutions were prepared in distilled ultra-pure water. All other reagents and solvents used in this work were of research-grade.

Liposome preparation. At molar ratio 7:2 of L- $\alpha$-Phosphatidylethanolamine derived from sheep brain to carboplatin (LipoCarbo) or $\beta$-cryptoxanthin (LipoCrypto) using the method of [21], neutral liposomal multilamellar vesicles (MLVs) were prepared.

In a round bottom flask of capacity $50 \mathrm{ml}$, $20 \mathrm{mg}$ of L- $\alpha$-Phosphatidylethanolamine and $3.06 \mathrm{mg}$ carboplatin (LipoCarbo) or $4.57 \mathrm{mg}$ $\beta$-cryptoxanthin (LipoCrypto) of the drug powder were mixed. Then $20 \mathrm{ml}$ of ethanol $(\mathrm{EtOH})$ was added, and the flask was shaken until all lipids dissolved in the EtOH. For a few minutes, the solution was well shacked then intense vortexing took place to ensure full solvation. The organic solvent was phased out using a rotary evaporator under vacuum provided by a circulating water aspiration vacuum pump in a warm water bath $\left(50^{\circ} \mathrm{C}\right)$ at $60 \mathrm{rpm}$ to create a uniform thin film of lipid on the inner wall of the flask. With Tris buffer $\left(\mathrm{pH} 7.4\right.$ in $\left.37^{\circ} \mathrm{C}\right)$ in a water bath at $50^{\circ} \mathrm{C}$. The lipid film was hydrated in a water bath at $50^{\circ} \mathrm{C}$ for $15 \mathrm{~min}$ at $60 \mathrm{rpm}$ to form multila- mellar vesicles (MLV) of liposomes. Following the same method as described above using only aliquots of L- $\alpha$-Phosphatidylethanolamine (Cephalin), control empty liposomes were prepared.

Size distribution and Zeta potential measurements. In Tris buffer ( $\mathrm{pH} \mathrm{7.4)} \mathrm{at} 25^{\circ} \mathrm{C}$ using a particle sizing system (Nanotrac Wave II, Microtrac, USA) for dynamic light scattering, the mean particle size, size distribution, and zeta potential of freshly prepared empty liposomes, LipoCarbo and LipoCrypto were calculated. The results were an average of three individual measurements.

DSC measurements. Using indium-calibrated differential scanning calorimetry (DSC) (model DSC-50, Shimadzu, Japan), the thermal properties of different lyophilized liposomal formulations were studied. On 5-mg samples sealed in standard aluminum pans the analyses are performed. The thermogram of each sample covers the $25-200^{\circ} \mathrm{C}$ temperature range at a scanning rate of $3^{\circ} \mathrm{C} / \mathrm{min}$.

FTIR Spectroscopy. On a Jasco FT/ IR-4100 spectrometer (Tokyo, Japan), FTIR spectra of lyophilized samples of empty L- $\alpha$ Phosphatidylethanolamine (Cephalin) liposomes and those carboplatin (LipoCarbo) liposomes or $\beta$-cryptoxanthin (LipoCrypto) deposited in $\mathrm{KBr}$ discs are registered. Scanning was performed at room temperature, at a speed of $2 \mathrm{~mm} / \mathrm{s}$ and a resolution of $4 \mathrm{~cm}-1$ in the range $400-4,000 \mathrm{~cm}^{-1}$.

In-Vitro cytotoxicity assay. Breast cancer cell line (MCF-7) was grown in a humidified incubator below $5 \% \mathrm{CO}_{2}$ and $95 \%$ air at $37{ }^{\circ} \mathrm{C}$ in RPMI 1640 media supplemented with penicillin $(100 \mathrm{IU} / \mathrm{ml})$, streptomycin $(100 \mu \mathrm{g} / \mathrm{ml})$, and decomplemented fetal bovine serum $(10 \%, \mathrm{v} / \mathrm{v})$. Drug treatments were carried out on 96 well culture plates (growth assays). For triplicate experiments, drugs were added to the culture medium at a calculated final concentration. By SRB (Sulfo-RhodamineB-stain) assay, the extent of the cell viability and proliferation (cell numbers) were measured. 
Cytotoxic activity of free carboplatin, free $\beta$-cryptoxanthin, carboplatin (LipoCarbo), or (LipoCrypto) $\beta$-cryptoxanthin-loaded liposomes was tested individually using the method of [22]. In order to permit adhesion of the cell to the wall of the plate MCF-7 cells were plated in 96-multi well plate $\left(10^{4}\right.$ cells/well) for $24 \mathrm{~h}$ before treatment with the applied drugs. Different concentrations of free carboplatin, free $\beta$-cryptoxanthin, carboplatin (LipoCarbo) or (LipoCrypto) $\beta$-cryptoxanthin-loaded liposomes under test (50, 100, 200, 400, 800, 1000, 1200, 1400, and $1500 \mu \mathrm{g} / \mathrm{ml}$ ) were applied to the cell monolayer triplicate wells were prepared for each dose in the laminar flow cabinet for more fertilization. Free carboplatin, LipoCarbo, and LipoCrypto were cocultivated with monolayer cells separately in an atmosphere of $5 \% \mathrm{CO}_{2}$ for $48 \mathrm{~h}$. Cells with SulfoRhodamine-B stain were fixed, washed, and stained after $48 \mathrm{~h}$. The excess stain was washed with acetic acid and the attached stain was recovered with TrisEDTA buffer. In an ELISA reader (ELISA- TECANSUNRISE, Germany), color intensity was evaluated. The relation between cell viability percentage (surviving fraction) and drug concentration is plotted to find the cell viability curve for MCF-7 cancer cell line after the treatment of plain Carboplatin, free $\beta$-cryptoxanthin, LipoCarbo, and LipoCrypto.

The percentage of cell survival was calculated as follows:

Survival fraction $=$ O.D. $($ treated cells $) /$ O.D. (control cells).

The $\mathrm{IC}_{50}$ values (drug concentrations needed to inhibit cell growth by $50 \%$ ). The experiment was repeated 3 times for each cell line.

Statistical analysis. All results are recorded as the mean \pm SD. Statistical analysis was performed by one-way variance analysis (ANOVA), where a commercially available software package (SPSS-17 for windows, SPSS Inc., Chicago, Illinois, USA), was used and the significance level was considered at $P<0.05$.

\section{Results and Discussion}

Dynamic light scattering (DLS) is a technique that is used in particle size measurement. Nano drug delivery systems improve the bioavailability of the entrapped drug according to their size which matches cell dimensions.

Table 1 shows the particle size for each formulation of carboplatin or $\beta$-cryptoxanthin -loaded liposomes as compared to empty liposomes. As
Table 1. Particle size distribution measured by dynamic light scattering (DLS) for various liposomal formulations

\begin{tabular}{l|c}
\hline Liposomal formulation & $\begin{array}{c}\text { Average size } \\
\text { vesicles, } \mathrm{nm}\end{array}$ \\
\hline Empty liposomes & $177.10 \pm 63.25$ \\
LipoCarbo & $1128.0 \pm 380.5$ \\
LipoCrypto & $153.80 \pm 11.17$ \\
\hline
\end{tabular}

can be observed from Table 1, the average particle size of the empty liposomal sample was concentrated around $177.10 \pm 63.25 \mathrm{~nm}$ mean size diameter. The incorporation of carboplatin (LipoCarbo) into liposomes resulted significantly $(P<0.05)$ in an increase in the calculated mean size diameter of blank liposomes from $177.10 \pm 63.25 \mathrm{~nm}$ to $1128.0 \pm 380.5 \mathrm{~nm}$. These findings show that carboplatin can be physically associated with carboplatin on the surface of liposomes and the carboplatin molecule tends to be hidden in the bilayer of lipids, which can clarify why the size is increased.

Upon the encapsulation of $\beta$-cryptoxanthin into liposomes (LipoCrypto), the mean vesicle sizes was decreased to be in the range of $153.80 \pm 11.17 \mathrm{~nm}$. These results indicate that the inclusion of $\beta$-cryptoxanthin into liposomes decreased the spacing between the adjacent bilayers resulting in the formation of liposomes smaller in size compared with the control ones. The reduction of particle size may be due to stronger $\beta$-cryptoxanthin interactions via hydrogen bonding with the lipid bilayer of liposomes. Within a smaller size range, liposomes favor the accumulation of drugs into certain target tissues. Besides, they also have good stability, thus displaying predictable drug-release rates.

The possible stability of the colloidal system is indicated by the magnitude of the zeta potential. If the zeta potential increases, there will be an increased repulsion between particles, leading to a more stable dispersion of colloids. If all suspended particles have a strong zeta potential that is negative or positive, they seem to repel each other, and the particles are not likely to join together. [23].

Following the findings of others, empty liposomes showed negative zeta potential $(-31.05 \pm 3.06 \mathrm{mV})$ [24-27]. $\beta$-cryptoxanthin-loaded liposomes (LipoCrypto) had higher negative zeta potential $(-34.51 \pm 3.33 \mathrm{mV})$ than blank liposomes and carboplatin (LipoCarbo) $(-21.60 \pm 2.99 \mathrm{mV})$ due 


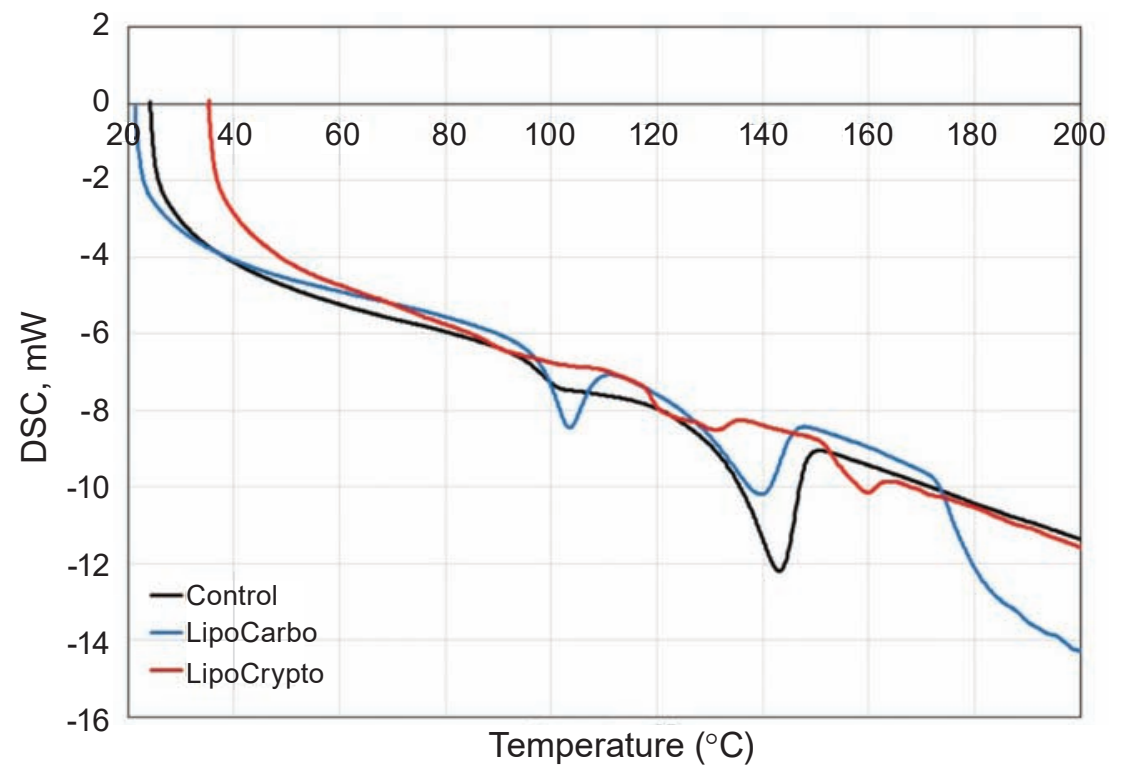

Fig. 3. DSC diagrams of liposomes are made of pure PE and liposomes doped with Carboplatin or $\beta$-cryptoxanthin

to the integration into the liposomal membranes. Within liposomal membranes, the incorporation of $\beta$-cryptoxanthin (LipoCrypto) appears to increase the density of negative charge and hence made the zeta potential negative.

The concept statement of DSC is that phospholipid vesicles undergo a reversible phase transition, under the effect of increasing temperature, from a 'gel' state to a 'liquid crystal' state. The pre-transition temperature $\left(\mathrm{T}_{\mathrm{p}}\right)$ at which a transition from the gel phase to the rippled phase takes place is primarily related to the phospholipid polar region. Subsequently, the melting of the bilayer from the rippled phase to the liquid phase occurs at the main transition temperature $\left(\mathrm{T}_{\mathrm{m}}\right)$. Changes in the lipid structure severely affect all the above phases.

When submitted for DSC analysis, pure L- $\alpha-$ Phosphatidylethanolamine (PE) vesicles upon dehydration when submitted to DSC analysis, showed a significant endothermic peak at $143^{\circ} \mathrm{C}$ (Fig. 3), in agreement with [28]. The pre-transition temperature $\left(\mathrm{T}_{\mathrm{p}}\right)$ was around $100^{\circ} \mathrm{C}$ for pure PE liposomes.

The introduction of carboplatin into PE liposomes showed a slight shift to a lower temperature at $140^{\circ} \mathrm{C}$ compared to the main endothermic peak (Tm) of empty PE that exists at $143^{\circ} \mathrm{C}$, indicating that carboplatin had a significant effect on PE bilayers' acyl chains, creating a conformational disorder within the phospholipid acyl chains and decreasing the transition cooperatively.
The lowered temperature of the main PE transition process suggested that carboplatin incorporation is more favored for the creation of a disordered and loose state of acyl chains. The pre-transition temperature $\left(\mathrm{T}_{\mathrm{p}}\right)$ peak for carboplatin liposomes has been moved to higher temperatures from $100^{\circ} \mathrm{C}$ to $103^{\circ} \mathrm{C}$, suggesting that it prefers a change from a tilted to a rippled chain gel phase.

Once $\beta$-cryptoxanthin was incorporated into $\mathrm{PE}$ liposomes, it resulted in distinct broadening and shift to higher temperature $160^{\circ} \mathrm{C}$ compared to the main characteristic endothermic peak $\left(\mathrm{T}_{\mathrm{m}}\right)$ of pure $\mathrm{PE}$ that exists at $143^{\circ} \mathrm{C}$, its intensity was markedly depressed.

The increased temperature of the main PE transition process indicated that the integration of $\beta$-cryptoxanthin is more proper for the creation of an ordered and cooperative state of acyl chains. The increase in PE phase transition, subsequently the reduction of the fluidity of the lipid bilayer membrane as a consequence of drug trapping. It has been found that the pre-transition temperature for $\beta$-cryptoxanthin liposomes was changed from $100^{\circ} \mathrm{C}$ to $127^{\circ} \mathrm{C}$, which has confirmed that it prefers a transformation from a tilted to a rippled chain gel phase. Using DSC, it was observed that the PE and carboplatin or $\beta$-cryptoxanthin mixtures displayed a single peak, which indicates that they are miscible.

Such changes observed in the current DSC work can be confirmed by FTIR, which was used to 
detect any vesicle structural alterations in the liposomal membrane structure by analyzing the wavenumber of different vibrational modes.

FTIR spectra of empty lyophilized PE liposomes compared with carboplatin or $\beta$-cryptoxanthin liposomal samples in the region of 4000 $400 \mathrm{~cm}^{-1}$ as shown in (Fig. 4). Two peaks are related to the symmetric and antisymmetric stretching vibrations of the $\mathrm{CH}_{2}$ in the acyl chain around 2850 and $2920 \mathrm{~cm}^{-1}$, respectively were apparent. The peak noticed near $1470 \mathrm{~cm}^{-1}$ is due to the $\mathrm{CH}_{2}$ bending vibration and that at $1734 \mathrm{~cm}^{-1}$ is due to the carbonyl stretching vibration $\mathrm{C}=\mathrm{O}$. Two peaks corresponding to the symmetric and antisymmetric $\mathrm{PO}_{2}{ }^{-}$stretching vibrations approximately at 1090 and $1220 \mathrm{~cm}^{-1}$, respectively were observed. These findings were in agreement with the data reported in the literature [29].

The detailed spectral analyses are performed in three distinct wavenumber regions, namely $3500-2500 \mathrm{~cm}^{-1}$ (Fig. 5), $1800-1500 \mathrm{~cm}^{-1}$ (Fig. 6), and $1800-800 \mathrm{~cm}^{-1}$ (Fig. 7).

Encapsulation of carboplatin or $\beta$-cryptoxanthin into the PE liposomes caused a shift in the wavenumber of the symmetric $\mathrm{CH}_{2}$ stretching bands in the acyl chain that appeared in Fig. 5, indicating that carboplatin or $\beta$-cryptoxanthin create a conformational disorder within the acyl chains of phospholipids.

The peak at $2844.489 \mathrm{~cm}^{-1}$ for the pure PE is moved towards higher wavenumber at $2847.381 \mathrm{~cm}^{-1}$ for carboplatin liposomes. This could imply an increase in the number of gauche conformers that indicates an increase in bilayer disorder [30]. The signal intensity became more intensive for carboplatin loaded liposomes. Once $\beta$-cryptoxanthin is integrated into PE, the peak for pure PE at $2844.489 \mathrm{~cm}^{-1}$ is moved to a higher wavenumber at $2845.453 \mathrm{~cm}^{-1}$, which suggests an increase in membrane fluidity and thus destabilization of the system in the gel phase (Fig. 5). The shifts to higher wavenumbers correspond to an increase in the number of gauche conformers [31]. The wavenumber of the $\mathrm{CH}_{2}$ stretching bands is significantly changed, showing that carboplatin or $\beta$-cryptoxanthin increased the number of gauche conformers and this suggests an increase in the conformational disorder (trans-gauche isomerization) of the bilayer.

The $\mathrm{C}=\mathrm{O}$ stretching band was analyzed for the interaction of carboplatin or $\beta$-cryptoxanthin with the backbone of glycerol near the head group of phospholipids in the interfacial region. The wavenumber variation of this band is shown in (Fig. 6). As can be seen from (Fig. 6), for the liposomal sample containing carboplatin or $\beta$-cryptoxanthin, the wavenumber value of the $\mathrm{C}=\mathrm{O}$ group at $1629.555 \mathrm{~cm}^{-1}$ was moved to higher wavenumbers at $1630.519 \mathrm{~cm}^{-1}$ for the liposomal sample containing carboplatin or $\beta$-cryptoxanthin without any evidence of hydrogen bonding formation. The absorption bands of ester $\mathrm{C}=\mathrm{O}$ are sensitive to changes in the polarity of their local environments and are affected by hydrogen

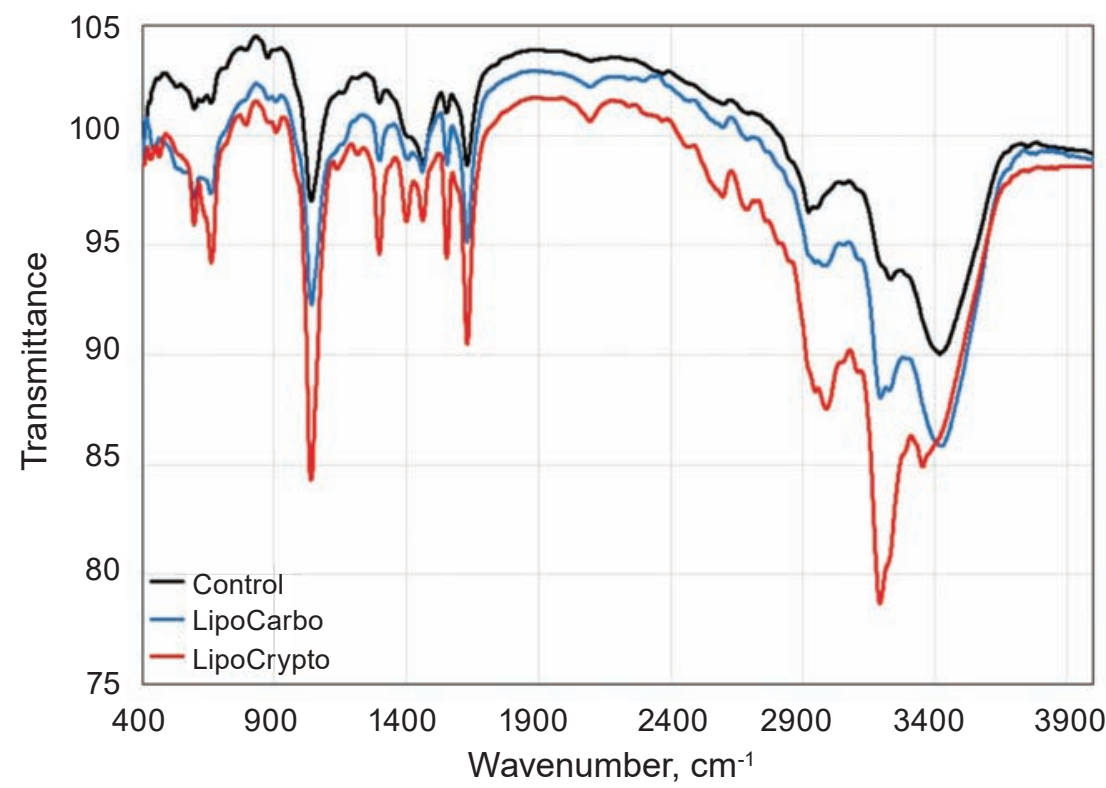

Fig. 4. The full FTIR spectra of empty PE and PE/carboplatin or $\beta$-cryptoxanthin liposomal samples 


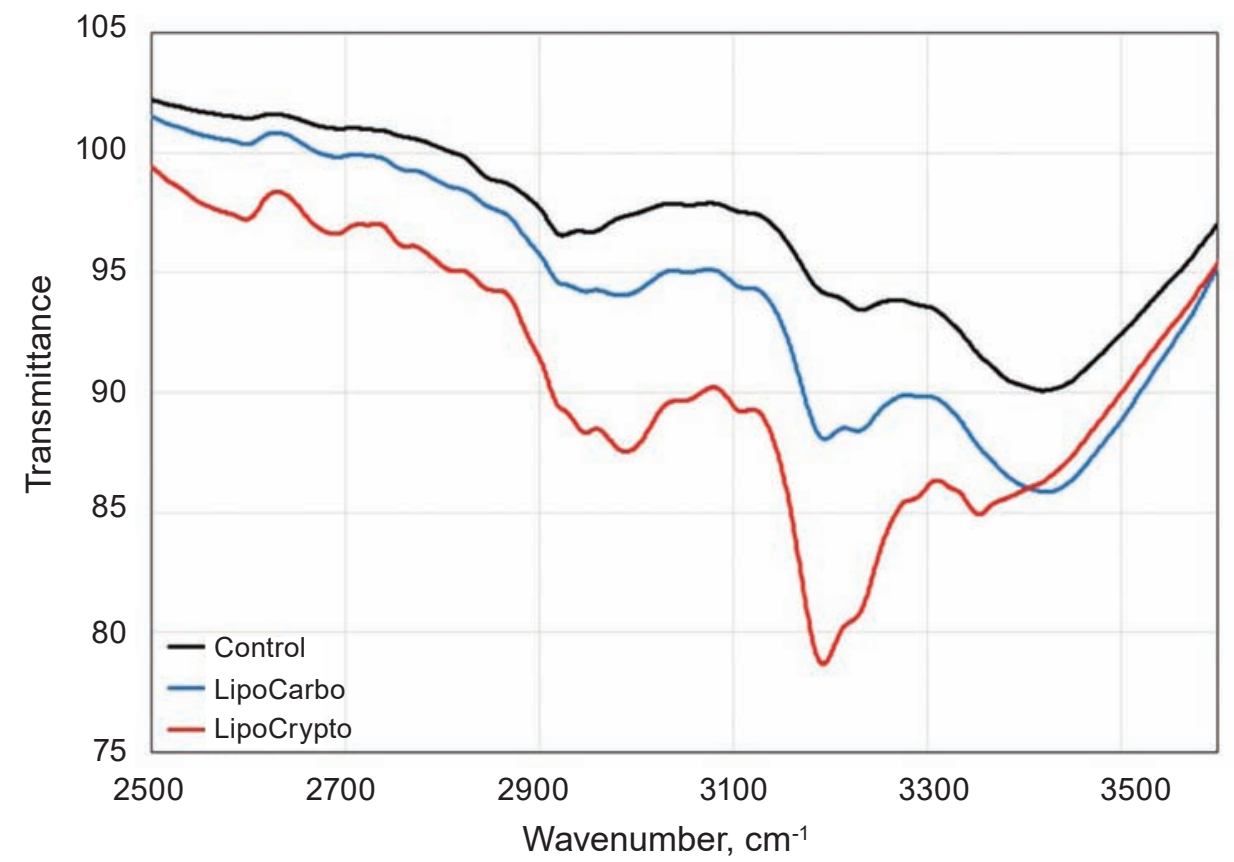

Fig. 5. The magnified part (3500-2500 $\left.\mathrm{cm}^{-1}\right)$ of FTIR spectra of empty PE and PE/carboplatin or $\beta$-cryptoxanthin liposomal samples

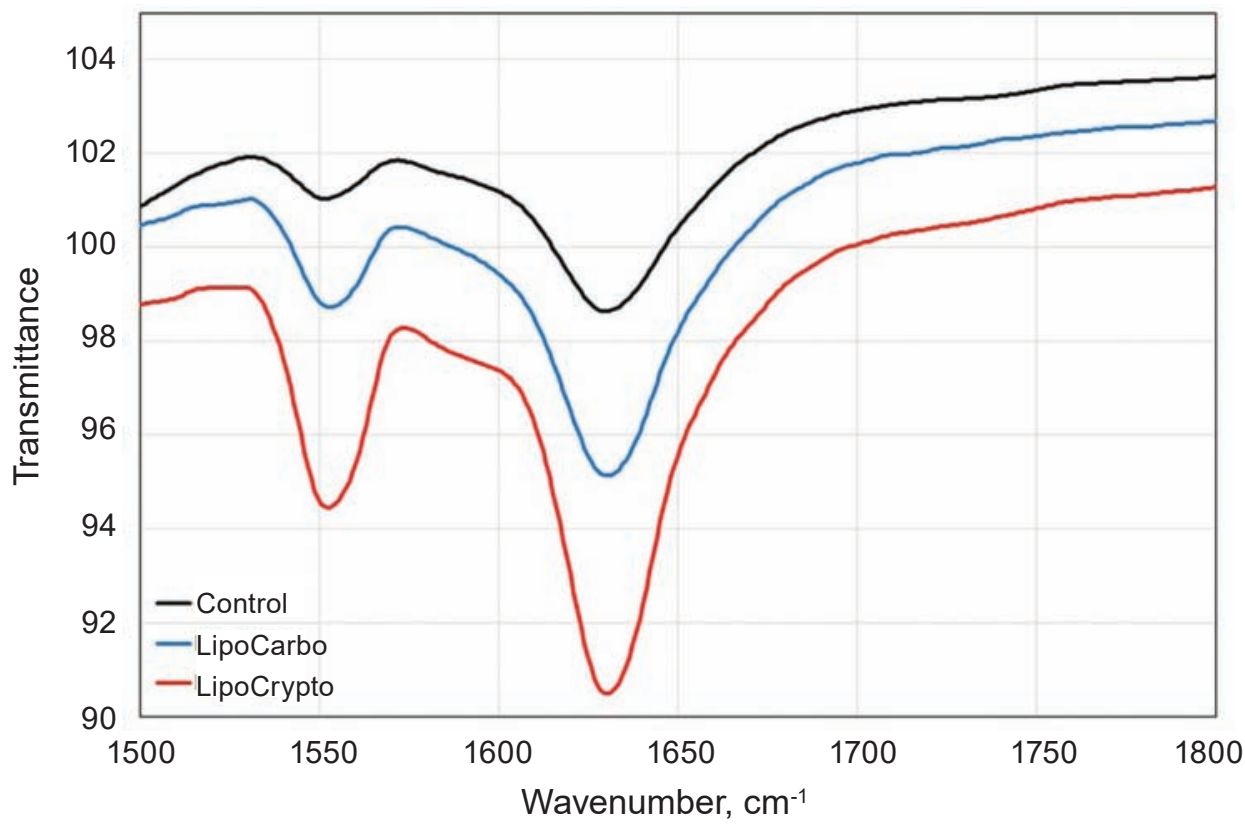

Fig. 6. The magnified part (1800-1500 $\left.\mathrm{cm}^{-1}\right)$ of FTIR spectra of empty PE and PE/carboplatin or $\beta$-cryptoxanthin liposomal samples

bonding and other interactions. Any variations in the spectra in this region may, therefore, be due to an interaction between carboplatin or $\beta$-cryptoxanthin and the membrane's polar/apolar interfacial region.

Utilizing the $\mathrm{PO}_{2}^{-}$antisymmetric stretching band, which is located at $1216.863 \mathrm{~cm}^{-1}$, the interaction between carboplatin or $\beta$-cryptoxanthin and the head group of PE liposomes was investigated. Fig. 7 shows the $\mathrm{PO}_{2}^{-}$antisymmetric stretching band for PE liposomes formulations in the absence and presence of carboplatin or $\beta$-cryptoxanthin. As can be seen from Fig. 7, the wavenumber was shifted to lower values after the addition of carboplatin $\left(1211.077 \mathrm{~cm}^{-1}\right)$ or $\beta$-cryptoxanthin $\left(1213.97 \mathrm{~cm}^{-1}\right)$ 


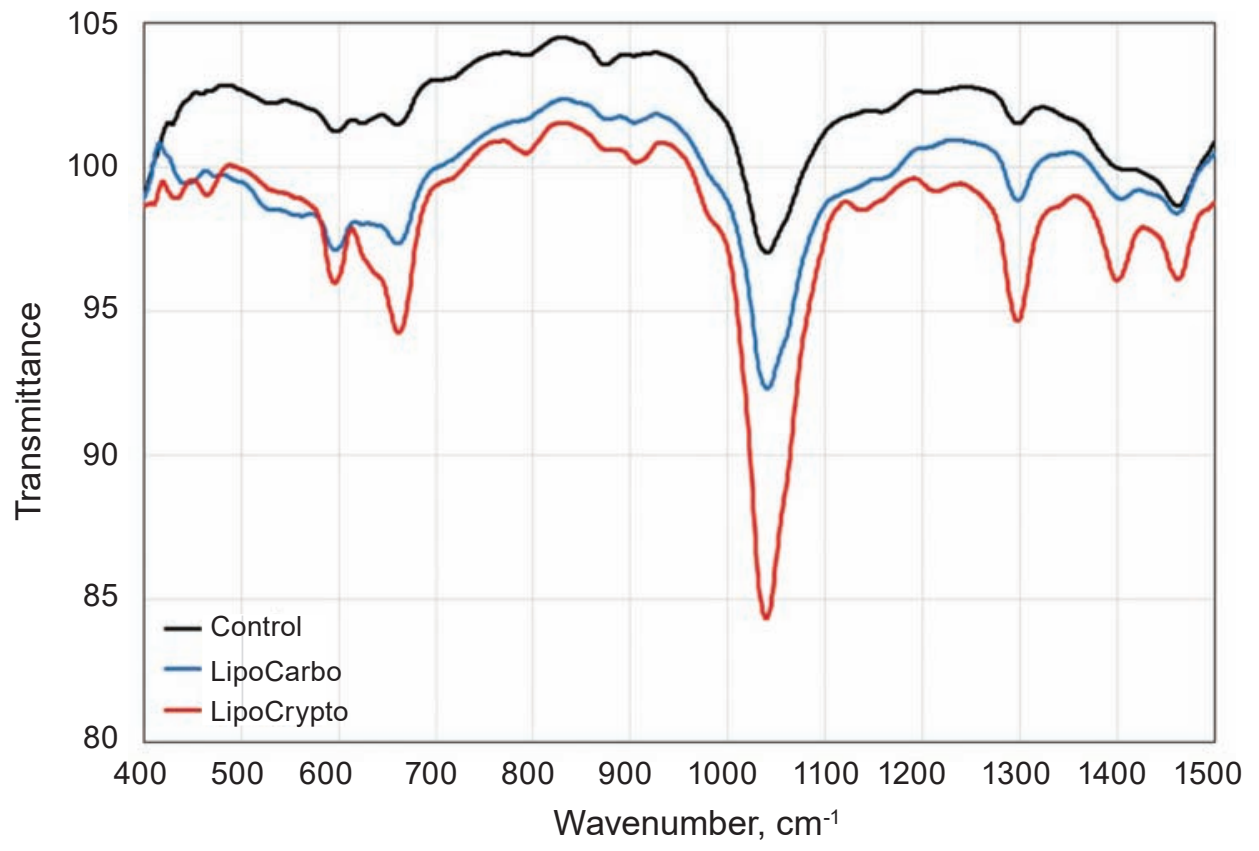

Fig. 7. The magnified part $\left(1800-1500 \mathrm{~cm}^{-1}\right)$ of FTIR spectra of empty PE and PE/carboplatin or $\beta$-cryptoxanthin liposomal samples

into PE liposomes. This implied the presence of hydrogen bonding between the liposome head group and carboplatin or $\beta$-cryptoxanthin. The decrease in the wavenumber value indicates a strengthening of existing hydrogen bonds or even a formation of new hydrogen bonding between the components [30].

The $\mathrm{CH}_{2}$ scissoring vibration mode which is located at $1461.778 \mathrm{~cm}^{-1}$ is influenced by the inclusion of $\beta$-cryptoxanthin into PE liposomal preparation. Following the encapsulation of $\beta$-cryptoxanthin into PE liposomes, the wavenumber was shifted towards higher values at $1462.742 \mathrm{~cm}^{-1}$. This could presume that the $\beta$-cryptoxanthin molecules act as small spacers of the polar head group, resulting in a slight disorder in the hydrocarbon chains. The wavenumber was shifted to a lower value at $1460.814 \mathrm{~cm}^{-1}$ after the encapsulation of carboplatin into PE liposomes.

After encapsulation of carboplatin or $\beta$-cryptoxanthin into $\mathrm{PE}$ liposomes, the $\mathrm{N}\left(\mathrm{CH}_{3}\right)_{3}^{+}$symmetric deformation band which is located at $1400.067 \mathrm{~cm}^{-1}$ was also modified (Fig. 7). This may be attributed to the presence of new intermolecular hydrogen bond formation between carboplatin or $\beta$-cryptoxanthin and $\mathrm{N}\left(\mathrm{CH}_{3}\right)_{3}^{+}$.

A shift to lower wavenumber $904.451 \mathrm{~cm}^{-1}$ was observed for the $\mathrm{CN}-\left(\mathrm{CH}_{3}\right)_{3}{ }^{+}$symmetric stretching band of choline at $905.4152 \mathrm{~cm}^{-1}$ by the inclusion of carboplatin/PE liposomal sample. In the polar head of PE, the existence of $\mathrm{N}\left(\mathrm{CH}_{3}\right)_{3}{ }^{+}$group might prevent the carboplatin $\mathrm{NH}_{3}^{+}$group from getting close to the polar head group because of the electrostatic repulsive force between the PE-N $\left(\mathrm{CH}_{3}\right)_{3}{ }^{+}$ group and the carboplatin $\mathrm{NH}_{3}^{+}$group; thus, weakening the interactions between phospholipid $\mathrm{N}\left(\mathrm{CH}_{3}\right)_{3}{ }^{+}$group and carboplatin $\mathrm{NH}_{3}^{+}$group. Table 2 shows the chemical shifts observed for LipoCarbo or LipoCrypto after the incorporation into L- $\alpha$ Phosphatidylethanolamine liposomes.

Using cell viability (in vitro cytotoxicity SRB) assay, the potential cytotoxic activity of the drug delivery system has been investigated at different drug concentrations of free carboplatin or carboplatin combined with liposomes and free $\beta$-cryptoxanthin or encapsulated into liposomes against breast carcinoma (MCF-7) cell line [22]. At zero concentration of each drug untreated cells served as controls. The assay was terminated at $48 \mathrm{~h}$ and measurements of cell viability were performed. The MCF-7 cancer cell line was incubated separately with different concentrations of drugs in the same sequence $(50$, 100, 200, 400, 800, 1000, 1200, 1400, and $1500 \mu \mathrm{g} /$ $\mathrm{ml}$ ), for $48 \mathrm{~h}$, (Fig. 8).

The highest cytotoxicity against MCF-7 cell line was observed for free $\beta$-cryptoxanthin or doped with liposomes (LipoCrypto) treated with the same series of different concentrations which applicable for the other drugs. At the highest free $\beta$-cryptoxanthin 
Table 2. The chemical shifts observed for LipoCarbo or LipoCrypto after the incorporation into L- $\alpha$ phosphatidylethanolamine liposomes

\begin{tabular}{|c|c|c|c|c|}
\hline \multirow[b]{2}{*}{ Peak assignment } & \multirow{2}{*}{$\begin{array}{l}\text { Wavenumber, } \\
\mathrm{cm}^{-1}\end{array}$} & \multicolumn{3}{|c|}{ Wavenumber, $\mathrm{cm}^{-1}$} \\
\hline & & $\begin{array}{c}\text { Control } \\
\text { Liposomes }\end{array}$ & LipoCarbo & LipoCrypto \\
\hline $\begin{array}{l}\text { Symmetric stretching vibration } \\
\text { of the } \mathrm{CH}_{2} \text { in the acyl chain }\end{array}$ & $(2800-2855)$ & 2844.489 & 2847.381 & 2845.453 \\
\hline $\begin{array}{l}\text { Carbonyl stretching } \\
\text { vibrations }(\mathrm{C}=\mathrm{O})\end{array}$ & $(1724-1740)$ & 1629.555 & 1630.519 & 1630.519 \\
\hline $\mathrm{CH}_{2}$ scissoring vibration & $(1457-1466)$ & 1461.778 & 1460.814 & 1462.742 \\
\hline $\begin{array}{l}\text { Antisymmetric } \mathrm{PO}_{2} \\
\text { stretching vibration }\end{array}$ & $(1215-1228)$ & 1216.863 & 1211.077 & 1213.97 \\
\hline$+\mathrm{N}-\mathrm{CH}_{3}$ symmetric deformation & $(1396-1405)$ & 1400.067 & 1403.924 & 1399.1028 \\
\hline $\begin{array}{l}\text { Symmetric stretching of } \\
\text { Choline } \mathrm{CN}-\left(\mathrm{CH}_{3}\right)_{3}\end{array}$ & $(904-930)$ & 905.4152 & 904.451 & 905.4152 \\
\hline
\end{tabular}

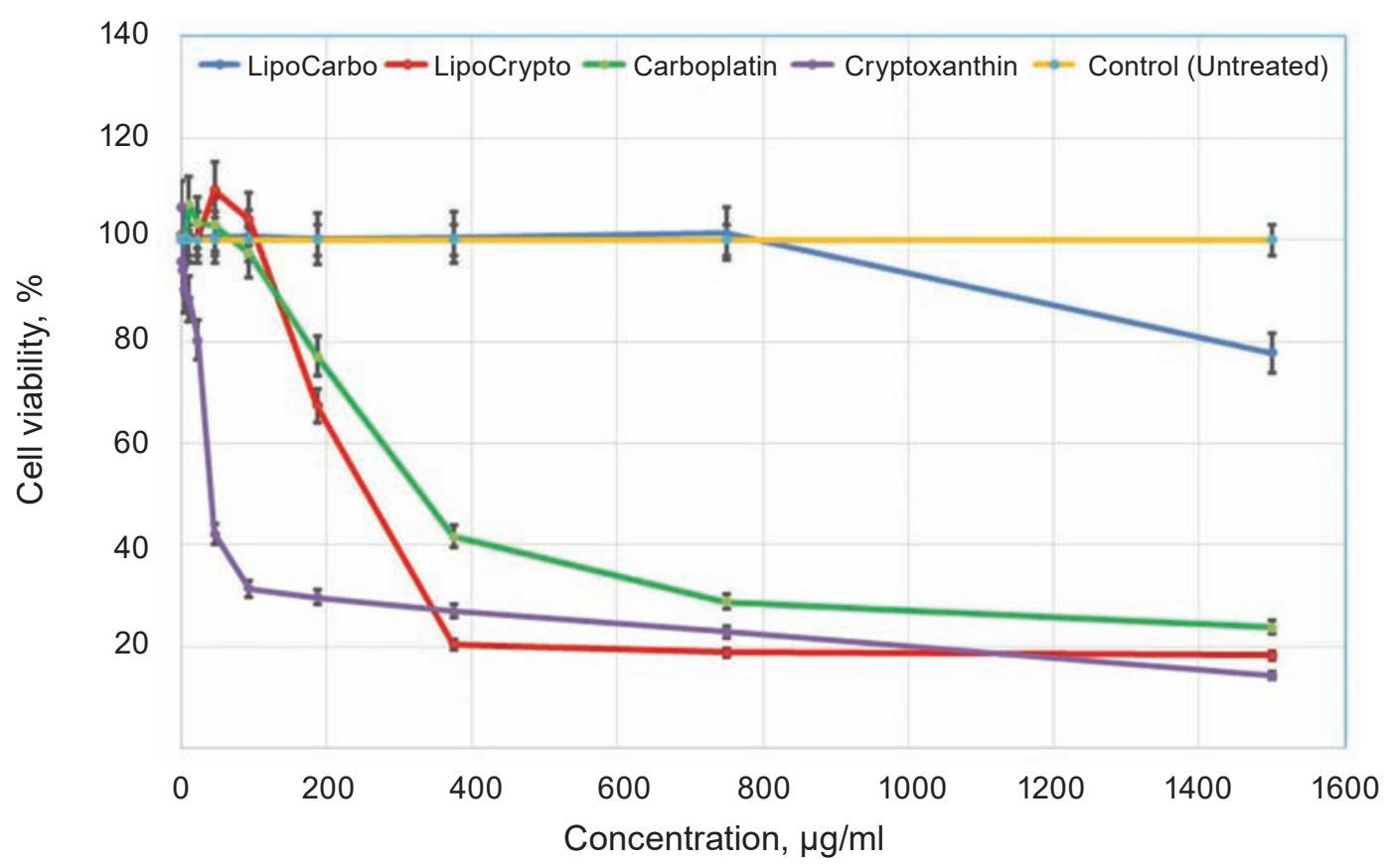

Fig. 8. Cytotoxicity of free carboplatin, free $\beta$-cryptoxanthin, and carboplatin or $\beta$-cryptoxanthin bound liposomes as opposed to untreated control breast carcinoma (MCF-7) cell line; incubated for $48 \mathrm{~h}$ with different concentrations $(50,100,200,400,800,1000,1200,1400$ and $1500 \mu \mathrm{g} / \mathrm{ml})$. The cell viability was determined using the SRB assay. The data represent the mean $\pm S D$ of triplicate experiments

or integrated into liposomes concentration $(1000 \mu \mathrm{g} /$ $\mathrm{ml})$, MCF-7 treated cells showed cell viability of approximately $20 \%(P<0.05), 48$ hours post-incubation. While the cell viability was approximately $30 \%$ $(P<0.05)$ for free carboplatin treated cells and approximately $90 \%$ for carboplatin-loaded liposomes at the same concentration $(1000 \mu \mathrm{g} / \mathrm{ml})$. For carbo- platin loaded liposomes (LipoCarpo) treated cells, the increase in cell viability compared to the free carboplatin could be attributed to the sustained release of carboplatin from liposomes.

At higher concentrations, cytotoxic activity between different formulations of drugs shows the order of free $\beta$-cryptoxanthin or its liposomal 




Fig. 9. $I C_{50}$ chart with significant values for free carboplatin, free $\beta$-cryptoxanthin or integrated into liposomes against breast carcinoma (MCF-7) cell line by using SRB assay, $48 \mathrm{~h}$ post-treatment

form $>$ carboplatin $>$ carboplatin-loaded liposomes according to Fig. 8.

At a lower concentration of approximately $42.17 \mu \mathrm{g} / \mathrm{ml}$, MCF-7 treated cells with free $\beta$-cryptoxanthin showed cell viability $42 \%(P<0.05)$ compared to its liposomal form of about $60 \%$, while $80 \%$ and $100 \%$ of the cell remained viable for carboplatin and its liposomal form (LipoCarbo), respectively Fig. 8.

In a cytotoxic assay with MCF-7 treated cells, the $\mathrm{IC}_{50}$ value for free $\beta$-cryptoxanthin was $23.43 \mu \mathrm{g} /$ $\mathrm{ml}(P<0.05)$, while carboplatin was counted $235 \mu \mathrm{g} /$ ml similarly in value with $\mathrm{IC}_{50}$ of MCF-7 treated cells with $\beta$-cryptoxanthin-loaded liposomes. It can be noticed that the $\mathrm{IC}_{50}$ of carboplatin-loaded liposomes (Lipocarbo) was not applicable in cytotoxic assay with MCF-7 Fig. 9. Natural medicine may be the perfect alternative for cancer treatment, eliminating the multiple physical side effects that chemotherapy can cause.

Conclusion. Our study shows that a combination of $\beta$-cryptoxanthin with liposomes shows synergistic growth inhibitory activity on breast carcinoma (MCF-7) cell line via induction of cytotoxicity. The current data suggest a new treatment regimen in which carboplatin is substituted with free $\beta$-cryptoxanthin or its liposomal form to enhance its anticancer activity against the MCF-7 cancer cell line. This finding provides a molecular basis for the development of natural compounds as novel anticancer agents and will allow lowering the dose of cytotoxic agents, which will in turn lead to more specific and less toxic therapies for mammary can- cer in humans. Liposomal carotenoids encapsulation increases their activity and decreases the concentration needed to give their desired actions.

Conflict of interest. Authors have completed the Unified Conflicts of Interest form at http://ukrbiochemjournal.org/wp-content/uploads/2018/12/ coi disclosure.pdf and declare no conflict of interest.

\section{ПОРІВНЯЛЬНА ЦИТОТОКСИЧНА ДІЯ КАРБОПЛАТИНУ ТА ß-КРИПТОКСАНТИНУ У ВІЛЬНІЙ ТА ЛІПОСОМНІЙ ФОРМАХ НА ЛІНІЮ КЛІТИН МОЛОЧНОЇ ЗАЛОЗИ}

\section{W. Shafaa ${ }^{\bowtie}$, N. S. Elkholy}

Physics Department, Medical Biophysics Division, Faculty of Science, Helwan University, Cairo, Egypt; 凶e-mail: medhatwi@hotmail.com

Дослідження ефективності антиканцерогенних сполук як синтетичного, так і природного походження у ліпосомній формі є актуальним для можливого їх застосування у терапії. $\mathrm{У}$ цій роботі використано алкілувальний агент карбоплатин та представник каротиноїдів $\beta$-криптоксантин. Метою дослідження було оцінити токсичну дію цих сполук у вільній та ліпосомній формах на клітини лінії MCF-7 раку молочної залози. За даними DSC та FTIR після додавання карбоплатину або $\beta$-криптоксантину до ліпосомних бішарів виявлено один пік, що вказує на їх змішування. У разі включення до ліпосом $\beta$-криптоксантину спостерігався більш упорядкований та кооперативний стан ацильних ланцюгів фосфатидилетаноламіну. Виявлено, що чутливість клітин MCF-7 до вільного $\beta$-криптоксантину була набагато вищою, ніж до вільного карбоплатину з $\mathrm{IC}_{50} 42$ та 235 мкг/мл відповідно. Значення $\mathrm{IC}_{50}$ для завантаженого у ліпосоми $\beta$-криптоксантину та для вільного карбоплатину були подібними, у той самий час не було виявлено цитотоксичного ефекту ліпосом, навантажених карбоплатином. Одержані дані дозволяють запропонувати заміну карбоплатину на $\beta$-криптоксантин у вільній або ліпосомальній формі як можливу схему для підвищення ефективності терапії раку молочної залози.

Кл юч ов і слова : $\beta$-криптоксантин, карбоплатин, ліпосоми, DSC, FTIR, клітини лінії MCF-7, цитотоксичність. 


\section{References}

1. Tarver T. Cancer facts \& figures, American cancer society (ACS) Atlanta, GA: American Cancer Society; 2012. P. 66.

2. Talluri SV, Kuppusamy G, Karri VV, Tummala S, Madhunapantula SV. Lipid-based nanocarriers for breast cancer treatment - comprehensive review. Drug Deliv. 2016; 23(4): 1291-1305.

3. Bozzuto G, Molinari A. Liposomes as nanomedical devices. Int J Nanomedicine. 2015; 10: 975-999.

4. Bangham AD, Hill MW, Miller NGA. In: Methods in Membrane Biology (Korn N.D., ed.) Plenum. N.Y., 1974. Vol.1, p.1.

5. Riaz M. Liposomes preparation methods. Pak J Pharm Sci. 1996; 9(1): 65-77.

6. Chang RS, Kim J, Lee HY, Han SE, Na J, Kim K, Kwon IC, Kim YB, Oh YK. Reduced doselimiting toxicity of intraperitoneal mitoxantrone chemotherapy using cardiolipin-based anionic liposomes. Nanomedicine. 2010; 6(6): 769-776.

7. Hwang JS, Tsai YL, Hsu KC. The feasibility of antihypertensive oligopeptides encapsulated in liposomes prepared with phytosterols- $\beta$ sitosterol or stigmasterol. Food Res Int. 2010; 43(1): 133-139.

8. Lobo V, Patil A, Phatak A, Chandra N. Free radicals, antioxidants and functional foods: Impact on human health. Pharmacogn Rev. 2010; 4(8): 118-126.

9. Go RS, Adjei AA. Review of the comparative pharmacology and clinical activity of cisplatin and carboplatin. J Clin Oncol. 1999; 17(1): 409422.

10. Perez EA. Carboplatin in combination therapy for metastatic breast cancer. Oncologist. 2004; 9(5): 518-527.

11. Milner JA. Molecular targets for bioactive food components. J Nutr. 2004; 134(9): 2492S-2498S.

12. Kris-Etherton PM, Hecker KD, Bonanome A, Coval SM, Binkoski AE, Hilpert KF, Griel AE, Etherton TD. Bioactive compounds in foods: their role in the prevention of cardiovascular disease and cancer. Am J Med. 2002; 113(Suppl 9B): 71S-88S.

13. Seshadri TR. Biochemistry of natural pigments; (exclusive of haeme pigments and carotenoids). Annu Rev Biochem. 1951; 20: 487-512.

14. Bartley GE, Scolnik PA. Plant carotenoids: pigments for photoprotection, visual attraction, and human health. Plant Cell. 1995; 7(7): 10271038.

15. Handelman GJ. The evolving role of carotenoids in human biochemistry. Nutrition. 2001; 17(10): 818-822.

16. Johnson EJ. The role of carotenoids in human health. Nutr Clin Care. 2002; 5(2): 56-65.

17. Stahl W, Sies H. Bioactivity and protective effects of natural carotenoids. Biochim Biophys Acta. 2005; 1740(2): 101-107.

18. Katsuura S, Imamura T, Bando N, Yamanishi R. beta-Carotene and beta-cryptoxanthin but not lutein evoke redox and immune changes in RAW264 murine macrophages. Mol Nutr Food Res. 2009; 53(11): 1396-1405.

19. Unno K, Sugiura M, Ogawa K, Takabayashi F, Toda M, Sakuma M, Maeda K, Fujitani K, Miyazaki H, Yamamoto H, Hoshino M. Betacryptoxanthin, plentiful in Japanese mandarin orange, prevents age-related cognitive dysfunction and oxidative damage in senescenceaccelerated mouse brain. Biol Pharm Bull. 2011; 34(3): 311-317.

20. Eid SY, El-Readi MZ, Wink M. Carotenoids reverse multidrug resistance in cancer cells by interfering with ABC-transporters. Phytomedicine. 2012; 19(11): 977-987.

21. Deamer DW, Uster PS: In liposomes. (Ostro MJ., ed), Dekker, New York; 1983. p. 27-51.

22. Skehan P, Storeng R, Scudiero D, Monks A, McMahon J, Vistica D, Warren JT, Bokesch H, Kenney S, Boyd MR. New colorimetric cytotoxicity assay for anticancer-drug screening. J Natl Cancer Inst. 1990; 82(13): 1107-1112.

23. Paolino D, Fresta M, Sinha P, Ferrari M. Drug delivery systems. In: Webster JG (ed.) Encyclopedia of medical devices and instrumentation, 2nd edn. Wiley, New York, 2006. P. 437-495.

24. Klein JW, Ware BR, Barcla G, Petty HR. Phospholipid dependence of calcium ion effects on electrophoretic mobilities of liposomes. Chem Phys Lipids. 1987; 43(1): 13-23.

25. Law SL, Lo WY, Pai SH, Teh GW. The electrokinetic behavior of liposomes adsorbed with bovine serum albumin. Int $J$ Pharmac. 1988; 43(3): 257-260.

26. Makino $K$, Yamada $T$, Kimura $M$, Oka $T$, Ohshima H, Kondo T. Temperature- and ionic strength-induced conformational changes in 
the lipid head group region of liposomes as suggested by zeta potential data. Biophys Chem. 1991; 41(2): 175-183.

27. Plank L, Dahl CE, Ware BR. Effect of sterol incorporation on head group separation in liposomes. Chem Phys Lipids. 1985; 36(4): 319328.

28. Koynova R, Caffrey M. Phases and phase transitions of the phosphatidylcholines. Biochim Biophys Acta. 1998; 1376(1): 91-145.

29. Mady MM, Shafaa MW, Abbase ER, Fahium AH. Interaction of doxorubicin and dipalmitoylphosphatidylcholine liposomes. Cell Biochem Biophys. 2012; 62(3): 481-486.

30. Severcan F, Sahin I, Kazanci N. Melatonin strongly interacts with zwitterionic model membranes - evidence from Fourier transform infrared spectroscopy and differential scanning calorimetry. Biochim Biophys Acta. 2005; 1668(2): 215-222.

31. Mady MM, Fathy MM, Youssef T, Khalil WM. Biophysical characterization of gold nanoparticles-loaded liposomes. Phys Med. 2012; 28(4): 288-295. 